\title{
Effect of Macronutrients, Bio-fertilizers and Growth Regulator on Yield and Yield Attributing Characters of Capsicum (Capsicum annuum L.)
}

\author{
Nikita Mohanty ${ }^{1 *}$, Ajoy Kumar Pattnaik ${ }^{1}$, Premananda Mahapatra ${ }^{1}$, \\ Nitish Kumar Jena ${ }^{2}$, Siddharth Kumar Rout ${ }^{1}$ and Mary Shiny Ekka ${ }^{1}$
}
${ }^{1}$ Department of Horticulture, Institute of Agricultural Sciences, Siksha 'O' Anusandhan
(Deemed to be University) Bhubaneswar, Odisha, India
${ }^{2}$ ICAR-Indian Institute of Water Management, Chandrasekharpur,
Bhubaneswar, Odisha, India

*Corresponding author

\section{A B S T R A C T}

\section{Keywords}

Capsicum, N: P: K,

Bio-fertilizers,

Growth regulator,

Yield

Article Info

Accepted:

20 January 2021

Available Online:

10 February 2021
The present investigation entitled "Effect of macronutrients, bio-fertilizers and growth regulator on yield and yield attributing characters of capsicum (Capsicum anпиит L.)" was carried out during Rabi Season, 2019-2020 at Research Farm, Chhatabara, Bhubaneswar. The recommended dose of fertilizer (RDF) used for capsicum was 120:60:120 kg NPK/ha along with FYM @ 15ton ha ${ }^{-1}$, where N was applied in three levels i.e., $100 \%, 75 \%$ and50 \% of the RDF with various combinations of bio-fertilizers (Azotobacter, Azospirillum and PSB in 1:1:1 ratio) and growth regulator (Planofix @ 200 ppm). The experiment was carried out to study the effect of bio-fertilizers and growth regulator at different levels of fertilizer on yield attributing character of Capsicum. Application of different levels of $\mathrm{N}$ with full dose of $\mathrm{P}, \mathrm{K}$ in combination with biofertilizers and growth regulator increase the yield and different yield attributing characters, where maximum number of fruits per plant $(8.23)$, length of fruits $(8.90 \mathrm{~cm})$, breadth of fruits $(9.60 \mathrm{~cm})$, single fruit weight $(45.32 \mathrm{~g})$ and fruit yield $(82.04 \mathrm{q} / \mathrm{ha})$ was observed in the same treatment. Thus, it may be suggested that recommended dose of fertilizer(120:60:120 kg NPK/ha) with bio-fertilizers $\left(1 \mathrm{~kg} \mathrm{plot}^{-1}\right)$ and growth regulator@ $200 \mathrm{ppm}$ application gave maximum yield in case of capsicum where all yield attributing characters mentioned above has topped the list.

\section{Introduction}

Capsicum (Capsicum annuum L.) is one of the very important commercial crops of India. It can be grown in tropical and sub-tropical regions which needs a warm humid climate. Thus, it can be grown in different types of soils, well-drained and loamy soils, in which organic matter are rich for its cultivation. Bell pepper is used in many ways as culinary preparations and a rich source of Vit $\mathrm{C}$ and $\mathrm{A}$. It has Anti-Cancer, Cardiovascular Benefits. It supports the Immune System. It is also a great source of Vitamin B6 and Magnesium. It cures Iron Deficiency. It lowers the cholesterol levels and triglycerides. It has 
detoxifying properties. Capsicum juice has proven to be effective in curing gastrointestinal disorders such as ulcers, diarrhoea and dyspepsia. It originated in new world tropics and subtropics (Greenleaf, 1986). In India, capsicum is cultivated over an area of 33,000 ha with annual production of 5.14 lakh MT and in Odisha, the crop is grown in an area of 4,600 ha with a production of 6,790 MT. Fruits is non-pungent with excellent aroma, hence called "sweet pepper" and "bell pepper" because of its bell-shaped fruit. Biofertilizers enhance availability of nutrients to the plants. Azospirillum is considered as associative symbiotic bacterium because it lives in close association with the root of plants. Azospirillum inoculation helps the plants in better vegetative growth and also saves nitrogenous fertilizers upto 25 to 30 per cent. Azospirillum fix nitrogen through an enzyme nitrogenase and also produce growth hormones IAA, GA and Cytokinin (Hubbel et al., 1979) and (Govindan and Nair, 1986). Azotobacter (nitrogenous biofertilizer) converts atmospheric nitrogen into ammoniacal form which is made available to plants. Potassium solubilizing biofertilizers are able to solubilize potassium minerals through production and excretion of organic acids (Friedrich et al., 1991).Phosphate solubilising bacteria (PSB), make more available phosphate in soil, supplied to the crop enhance the fertilizer use efficiency, soil fertility status and ensures partial savings of fertilizers which in terns reduce the cost of cultivation. (Ghoname, A. and Shafeek, M.R., 2005). The integrated nutrient supply to an optimum level is possible only through judicious and efficient use of mineral fertilizers, bio-fertilizers, green manures, organic manures and crop residues (Tilak and Singh, 1996).

Organic manures are very cheap and easily available, apart from partially fulfilling the nutrient demand, improve soil structure, enhance fertility and promote biological activity. The organic manure gives better quality produce as compared to those grown with the inorganic source of fertilizer (Abusaleha and Shanmugavelu, 1988).Biofertilizers are economically viable, ecologically sound and also are selfgenerating sources without any negative influence either to the crop or to the environment. For enhancing yield of vegetable crops, soil health is crucial factor. Enhancing soil fertility and crop productivity through use of chemical fertilizers has often negatively affected the complex system of bio-geo-chemical cycles (Roberts, 2008). The excessive use of 2 chemical fertilizers created series of problems including soil degradation, poor quality production, environmental pollution and hazard to human health. Application of chemical fertilizers alone supply only one or two nutrient elements to the crop. On the other, supplying only organic inputs can improve soil physical and biological environment but suffers from drawback of low content of plant nutrients. The integrated use of chemical fertilizers, biofertilizers and growth hormones hold great promise in securing high level of crop productivity with good quality and also protect soil health from deterioration and pollution hazards. Therefore, there is a need to develop suitable integrated nutrient management technology which will go a long way in building of soil fertility and productivity of bell pepper.

In Odisha, practically much research has not yet been done in Capsicum with reference to application of different levels of $\mathrm{N}, \mathrm{P}, \mathrm{K}$ in combination with bio-fertilizers along with growth regulator in capsicum. Hence this experiment was undertaken to observe the effects of macronutrients and bio-fertilizers along with growth regulator on yield and yield attributing characters of capsicum. 


\section{Materials and Methods}

The present research entitled "Effect of macronutrients, bio-fertilizers and growth regulator on yield and yield attributing characters of capsicum (Capsicum annиum L.)" was carried out during Rabi Season, 2019-2020 at Research Farm, Chhatabara, Bhubaneswar. The experiment was carried out to study the effect of bio-fertilizers and growth regulator at different levels of fertilizer on yield and yield attributing characters of Capsicum. Variety Ayesha was selected. Ten treatments using different recommended dose of fertilizer (NPK: 120:60:120), FYM (15ton ha ${ }^{-1}$ ), bio-fertilizers (Azotobacter, Azospirillum and PSB were used in 1:1:1 ratio@ $1 \mathrm{~kg} \mathrm{plot}^{-1}$ ) and growth regulator (Planofix @ 200 ppm) were applied in different treatments. The sowing was done in rabi season using RBD. The sowing spacing of $50 \mathrm{~cm} \times 50 \mathrm{~cm}$ was taken in $3 \mathrm{~m} \mathrm{x}$ $3 \mathrm{~m}$ of each treatment with total area of 270 sqm. From each plot five observation plants were selected from each treatment to record the number of fruits per plant, length of fruits, breadth of fruits, single fruit weight and fruit yield. The details of the treatments applied in this experiment are given in Table 1.

\section{Results and Discussion}

Significant variation on no. fruits per plant was observed in the experiment, which is presented in table 2 and Fig 1. Maximum fruits per plant was observed in $T_{8}$ (8.23) followed by $T_{9}(6.60)$ and $T_{2}$ (4.63) but $T_{8}$ was significantly superior to all other treatments tried in this experiment. The fruits per plant vary from 8.23 to 3.20 . However, the higher dose of NPK with bio-fertilizers and growth regulator increase the number of fruits per plant over control. This may be due to the apportioning efficiency that is increased allocation of photosynthates towards the economic part i.e., fruit and also the solubilization effect of plant nutrients by addition of FYM as evinced by the uptake of $\mathrm{N}, \mathrm{P}, \mathrm{K}, \mathrm{Ca}$ and $\mathrm{Mg}$ by the crop during the vegetative stage as well as reproductive phase. This result is in confirmation with Shaheen et al., (2016) and Shelat et al., (2017).

Significant differences were also exhibited among different treatments with respect to fruit length and was presented in Table 2, Fig. 2 , it revealed that maximum length of fruit was marked with $\mathrm{T}_{8}(8.90 \mathrm{~cm})$ followed by $\mathrm{T}_{9}$ $(7.63 \mathrm{~cm})$ and $T_{2}(7.50 \mathrm{~cm})$ which was significantly superior to other treatments tried in this experiment. The minimum length of the fruit was recorded with $\mathrm{T}_{7}(6.50 \mathrm{~cm})$ and was significantly inferior than other treatments. The maximum length of the fruit was seen in $\mathrm{T}_{8}(8.90 \mathrm{~cm})$ which is significantly superior than all other treatments tried in the experiment with respect to the combined effect of $100 \% \mathrm{~N}, \mathrm{P}, \mathrm{K}$, of with bio-fertilizers and growth regulator as organic source over other treatments including control. However, the other treatments carried out in this experiment could not increase the length of the fruits which is in conformation with Dipika et al., (2017) and Kumbar et al., (2017).

The maximum breadth of the fruit was seen in $\mathrm{T}_{8}(9.60 \mathrm{~cm})$ which is significantly superior than all other treatments tried in the experiment was presented in Table 2 and Fig 3 , The smallest fruits are seen in $T_{7}(6.43 \mathrm{~cm})$. The breadth of fruit was found to be significant with respect to the combined effect of $100 \% \mathrm{~N}, \mathrm{P}, \mathrm{K}$, of with bio-fertilizers and growth regulator as organic source over other treatments including control. However, the other treatments carried out in this experiment could not increase the breadth of the fruits which is in conformation with Dipika et al., (2017) and Kumbar et al., (2017). 
From the Table 2 and Fig. 4, it can clearly be revealed that the fruit weight varies significantly in different treatments. The highest individual fruit weight was marked in
$\mathrm{T}_{8}$ (45.32 $\mathrm{g}$ ) which was significantly superior to other treatments and the lowest value was recorded with $\mathrm{T}_{7}(16.74 \mathrm{~g})$ which was significantly inferior to rest of the treatments.

Table.1 The experiment comprised of the following treatments

\begin{tabular}{|c|l|}
\hline Treatments & \multicolumn{1}{c|}{ Treatment details } \\
\hline $\mathbf{T}_{\mathbf{1}}$ & Control = Recommended dose of NPK @ 120:60:120 $\mathrm{kg} \mathrm{ha}^{-1}$ \\
\hline $\mathbf{T}_{\mathbf{2}}$ & $100 \% \mathrm{~N}+$ Full P and K + Bio-fertilizers \\
\hline $\mathbf{T}_{\mathbf{3}}$ & $75 \% \mathrm{~N}+$ Full P and K + Bio-fertilizers \\
\hline $\mathbf{T}_{\mathbf{4}}$ & $50 \% \mathrm{~N}+$ Full P and K + Bio-fertilizers \\
\hline $\mathbf{T}_{\mathbf{5}}$ & $100 \% \mathrm{~N}+$ Full P and K + Planofix @ 200 ppm \\
\hline $\mathbf{T}_{\mathbf{6}}$ & $75 \% \mathrm{~N}+$ Full P and K + Planofix @ 200 ppm \\
\hline $\mathbf{T}_{\mathbf{7}}$ & $50 \% \mathrm{~N}+$ Full P and K + Planofix @ 200 ppm \\
\hline $\mathbf{T}_{\mathbf{8}}$ & $100 \% \mathrm{~N}+$ Full P and K + Bio-fertilizers + Planofix @ 200 ppm \\
\hline $\mathbf{T}_{\mathbf{9}}$ & $75 \% \mathrm{~N}+$ Full P and K + Bio-fertilizers + Planofix @ 200 ppm \\
\hline $\mathbf{T}_{\mathbf{1 0}}$ & $50 \% \mathrm{~N}+$ Full P and K + Bio-fertilizers + Planofix @ 200 ppm \\
\hline
\end{tabular}

Table.2 Effect of fertilizer levels, bio-fertilizers and growth regulator on yield and yield attributing characters of Capsicum var. Ayesha

\begin{tabular}{|c|c|c|c|c|c|c|}
\hline Treatment & Treatment detail & $\begin{array}{l}\text { Number } \\
\text { of fruits } \\
\text { / plants }\end{array}$ & $\begin{array}{c}\text { Fruit } \\
\text { length } \\
\text { (cm) }\end{array}$ & $\begin{array}{c}\text { Fruit } \\
\text { breadth } \\
\text { (cm) }\end{array}$ & $\begin{array}{c}\text { Fruit } \\
\text { weight } \\
\text { (g) }\end{array}$ & $\begin{array}{c}\text { Yield } \\
\text { / ha } \\
\text { (q) }\end{array}$ \\
\hline$T_{1}$ & $\begin{array}{l}\text { Control = Recommended dose of } \\
\text { NPK @ 120:60:120 kg ha }\end{array}$ & 3.87 & 7.23 & 7.27 & 31.09 & 35.22 \\
\hline $\mathbf{T}_{2}$ & $100 \% \mathrm{~N}+$ full PK + Bio-fertilizers & 4.63 & 7.50 & 8.13 & 34.72 & 57.79 \\
\hline $\mathbf{T}_{3}$ & $75 \% \mathrm{~N}+$ full PK + Bio-fertilizers & 3.90 & 7.07 & 8.00 & 33.69 & 42.28 \\
\hline $\mathbf{T}_{4}$ & $50 \% \mathrm{~N}+$ full PK + Bio-fertilizers & 3.33 & 6.73 & 6.53 & 17.10 & 28.41 \\
\hline$T_{5}$ & $100 \% \mathrm{~N}+$ full PK + Planofix & 3.80 & 7.47 & 7.57 & 32.75 & 56.98 \\
\hline$T_{6}$ & $75 \% \mathrm{~N}+$ full PK + Planofix & 3.73 & 6.87 & 7.13 & 24.08 & 48.77 \\
\hline $\mathbf{T}_{7}$ & $50 \% \mathrm{~N}+$ full PK + Planofix & 3.20 & 6.50 & 6.43 & 16.74 & 27.94 \\
\hline $\mathbf{T}_{8}$ & $\begin{array}{l}100 \% \mathrm{~N}+\text { full PK + Bio-fertilizers } \\
+ \text { Planofix }\end{array}$ & 8.23 & 8.90 & 9.60 & 45.32 & 82.04 \\
\hline $\mathbf{T}_{9}$ & $\begin{array}{l}75 \% \mathrm{~N}+\text { full PK + Bio-fertilizers } \\
\text { + Planofix }\end{array}$ & 6.60 & 7.63 & 8.17 & 36.95 & 68.25 \\
\hline \multirow[t]{5}{*}{$\mathbf{T}_{10}$} & $\begin{array}{l}50 \% \mathrm{~N}+\text { full PK + Bio-fertilizers } \\
+ \text { Planofix }\end{array}$ & 3.60 & 7.07 & 7.00 & 17.34 & 32.46 \\
\hline & $\operatorname{Sem}( \pm)$ & 0.41 & 0.34 & 0.44 & 2.31 & 4.08 \\
\hline & $\mathrm{CD}(5 \%)$ & 1.21 & 1.00 & 1.30 & 6.85 & 12.12 \\
\hline & $\mathrm{CV}(\%)$ & 15.70 & 8.03 & 9.98 & 13.78 & 14.72 \\
\hline & 'F' test & $\mathrm{S}$ & $\mathrm{S}$ & $\mathrm{S}$ & $\mathrm{S}$ & $\mathrm{S}$ \\
\hline
\end{tabular}


Fig.1 Effect of fertilizer levels, bio-fertilizers and growth regulator on Number of fruits/plants of Capsicum var. Ayesha

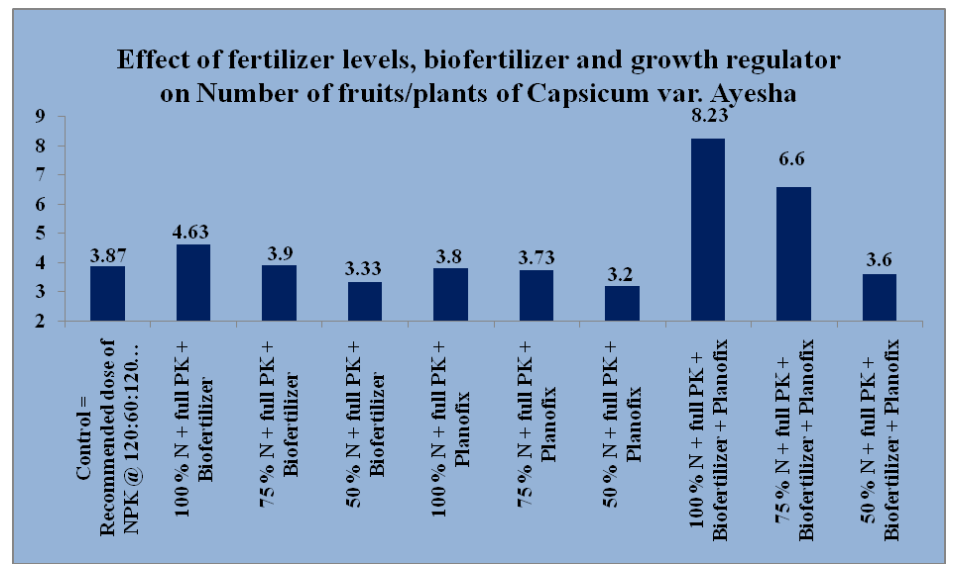

Fig.2 Effect of fertilizer levels, bio-fertilizers and growth regulator on Number of Fruit length (cm) of Capsicum var. Ayesha

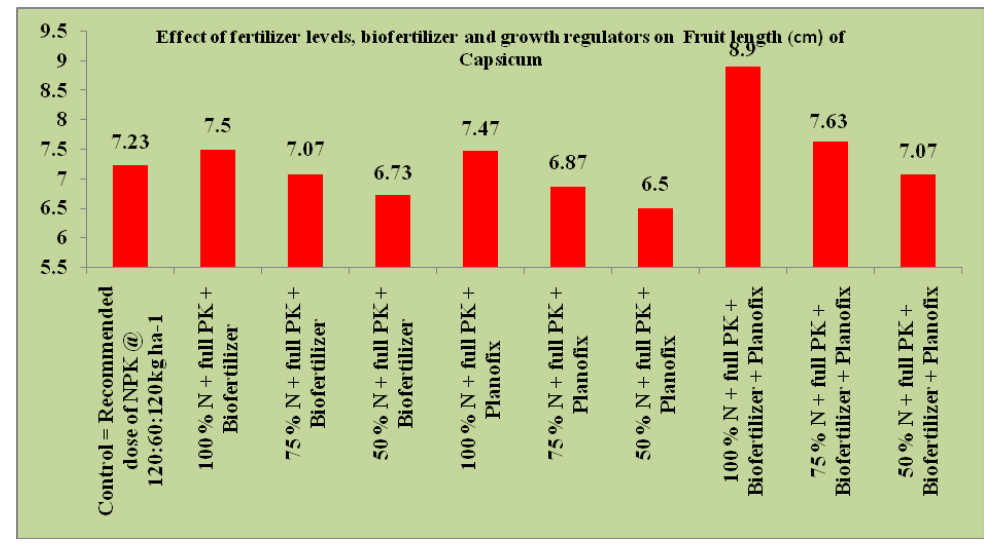

Fig.3 Effect of fertilizer levels, bio-fertilizers and growth regulator on Fruit breadth $(\mathrm{cm})$ of Capsicum

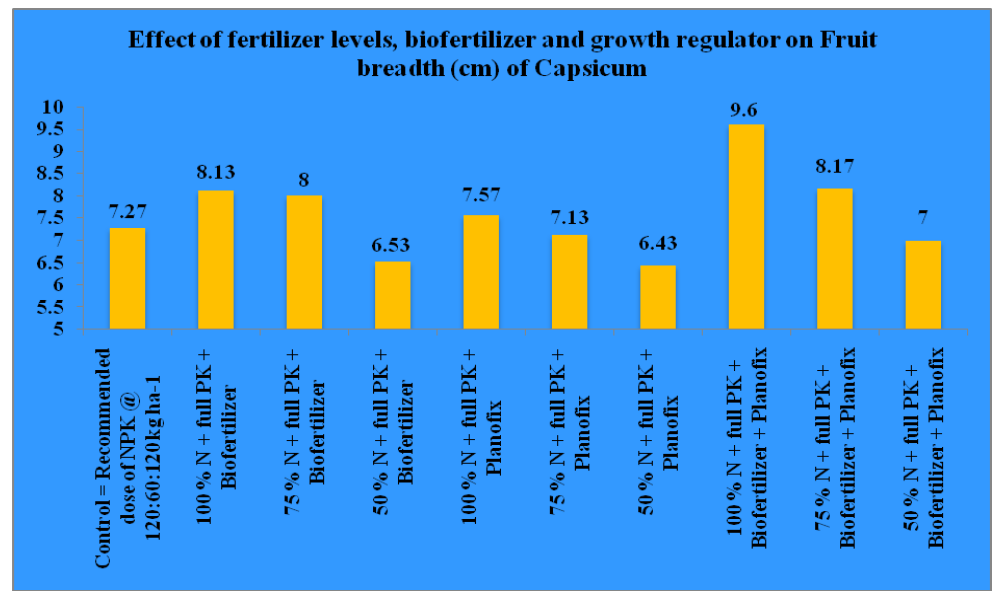


Fig.4 Effect of fertilizer levels, bio-fertilizers and growth regulator on Fruit weight (g) of Capsicum

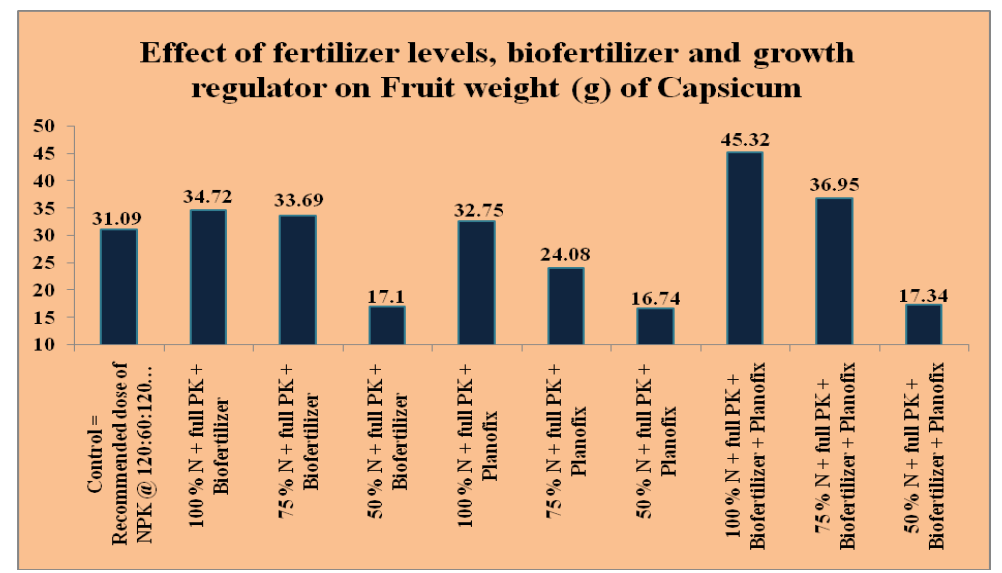

Fig.5 Effect of fertilizer levels, bio-fertilizers and growth regulator on Fruit yield (q/ha) of Capsicum

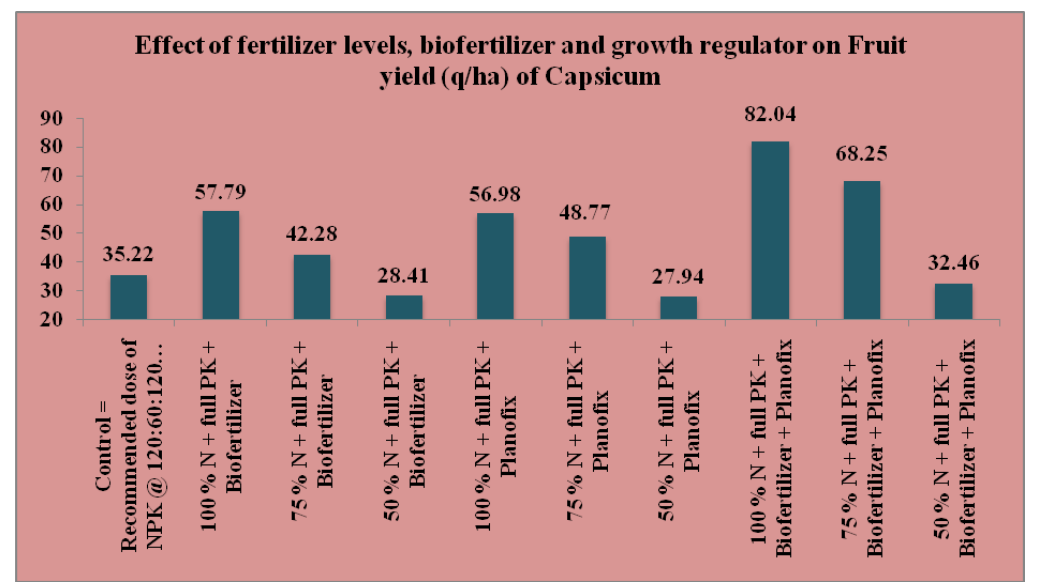

Fig.6 Fruit yield from sample plant in $\mathrm{T}_{8}$
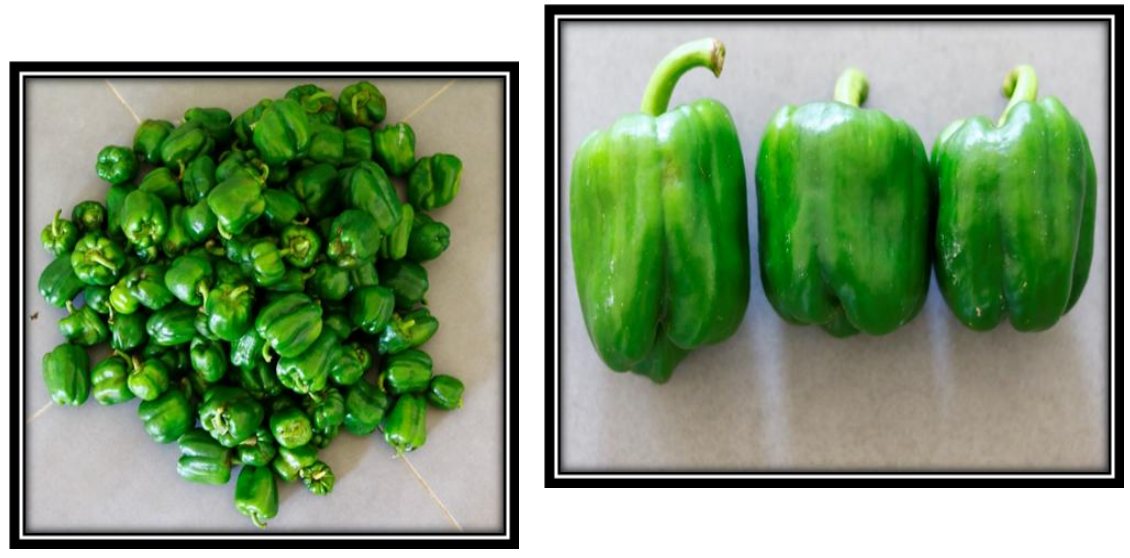
The analysis also showed similar trends with maximum fruit weight in $\mathrm{T}_{8}(45.32 \mathrm{~g})$ followed by $\mathrm{T}_{9}(36.95 \mathrm{~g})$ and $\mathrm{T}_{2}(34.72 \mathrm{~g})$ which was significantly superior than all other treatments tried in the experiment. The minimum fruit weight was seen in $\mathrm{T}_{7}(16.74 \mathrm{~g})$ with $\mathrm{T}_{4}$ $(17.10 \mathrm{~g})$. The weight of the fruit was found to be significant with respect to the combined effect $100 \% \mathrm{~N}, \mathrm{P}, \mathrm{K}$ of recommended dose of chemical fertilizer along with bio-fertilizers and growth regulator over other treatments. Large sized fruits with increased weight were recorded by applying $100 \% \mathrm{~N}, \mathrm{P}, \mathrm{K}$ along with biofertilizers and growth regulator which might have favoured the production of more amount of food materials and accumulation of same in the fruit, thereby increasing the individual fruit weight (Plate). The result is in confirmation with Dipika et al., (2017) and Kumbar et al., (2017).

A significant variation in total fruit yield due to different treatments was recorded in the present experiment conducted in the year 2019-2020 in rabi season which varied between 27.94 to $82.04 \mathrm{q} \mathrm{ha}^{-1}$ (Table 2, Fig. 5 and 6). All the treatments had exhibited higher value than $\mathrm{T}_{7}$ (27.94 $\mathrm{q} \mathrm{ha}^{-1}$ ) Among the treatments tried, maximum yield was recorded with $\mathrm{T}_{8}(82.04 \mathrm{q}$ $\mathrm{ha}^{-1}$ ) which was significantly superior to rest of the treatments tried in this experiment. The lowest yield was recorded with $\mathrm{T}_{7}(27.94 \mathrm{q}$ ha $\left.{ }^{1}\right)$. Different treatments followed in the order of $\mathrm{T}_{8}>\mathrm{T}_{9}>\mathrm{T}_{2}>\mathrm{T}_{5}>\mathrm{T}_{6}>\mathrm{T}_{3}>\mathrm{T}_{1}>\mathrm{T}_{10}>\mathrm{T}_{4}$. Fruit yield per ha showed significantly difference among the treatments in the experiment. However, lowest fruit yield was recorded in the treatment with a dose of $50 \% \mathrm{~N}, \mathrm{P}, \mathrm{K}$ along with growth regulator which was significantly inferior to other treatments.

Application of different level of nitrogen, phosphorus and potassium in combination with bio-fertilizers and growth regulator increase the yield of fruits per plant in an increasing order with that of increase dose of N P K with biofertilizers and growth regulator. The maximum fruit yield per ha was recorded by giving $100 \%$ $\mathrm{N}, \mathrm{P}, \mathrm{K}$, along with bio-fertilizers and growth regulator, which is superior to other treatments tried out in this experiment followed by $75 \% \mathrm{~N}$, $\mathrm{P}, \mathrm{K}$, with bio-fertilizers and growth regulator and $100 \% \mathrm{~N}, \mathrm{P}, \mathrm{K}$ along with bio-fertilizers. The increase in the yield could be due to greater availability of nutrient in soil and inoculation resulting in better growth and development which might be attributed to better mobilization of different nutrients and increased allocation of photosynthesis towards the economic parts and also hormonal balance on the plant. The findings corroborate with the findings of Laxman Singh and S Mukherjee (2000), Shaheen et al., (2016), Kumbar et al., (2017), Sahoo et al., (2017), Shilpa et al., (2017), Nchang et al., (2018).

In conclusion the salient findings of the present study, entitled "Effect of macronutrients, biofertilizers and growth regulator on yield and yield attributing characters of capsicum (Capsicum annuum L.)" clearly indicates that significant variation having maximum number of fruits per plant (8.23) was recorded in the treatment receiving $100 \%$ RDF (120:60:120 NPK kg ha ${ }^{-1}$ ) in combination with biofertilizers treatment and growth regulator spray. Also, significantly maximum length of fruits $(8.90 \mathrm{~cm})$, highest breadth of fruits $(9.60 \mathrm{~cm})$, single fruit weight $(45.32 \mathrm{~g})$ and maximum fruit yield $(82.04 \mathrm{q} / \mathrm{ha})$ was also observed in the above treatment, which all were significantly superior to rest other treatments. Increase the yield and yield attributing characters in above treatment $\mathrm{T}_{8}$ might be due to the combined effect of bio-fertilizers $(1 \mathrm{~kg} / \mathrm{plot})$ and growth regulator @200 ppm with different levels of $\mathrm{N}: \mathrm{P}: \mathrm{K} \mathrm{kg} \mathrm{ha} \mathrm{ha}^{-1}(120: 60: 120)$ which in turn expressed better yield and other yield attributing characters in Capsicum.

\section{References}

Abusaleha, and Shanmugavelu, K.G. 1988. Studies on the effect of organic vs. Inorganic sources of nitrogen on growth, yield and quality of okra (Abelmoschus esculentus). Indian J. Hort. 45(3-4): 312318. 
Friedrich, S., Platonova, N.P., Karavaiko, G. I., Stichel, E. and Glombitze, F. 1991. Chemicals and microbiological solubilization of silicates. Acta Biotech., 11: 187-96.

Ghoname, A, Shafeek, MR. 2005. Growth and productivity of sweet pepper (Capsicum annum L.) grown in plastic houses as affected by organic, mineral and bio-Nfertilizer. J. Agron.; 4:369-372.

Govindan, M., Nair, R.R. 1986. Azospirillum rhizocoenosis in pepper.In: Proceedings of National Seminar on Microbial Ecology. Tamil Nadu Agricultural University, Coimbatore.

Greenleaf, W. H. 1986. Pepper breeding. (In) Breeding Vegetable Crops. AVI, West Port, pp. 67-134.

Hubbel, D.H., Tien, T.M., Gaskins, M.H., Lee, J. 1979. Physiological interaction in the Azospirillum - Grass root association. In (Eds Vose P B and RuschelA P) Associative N2 fixation.

Kumbar, H., Raj, A.C. and Hore, J.K. 2017. Effect of Bio-fertilizers and Inorganic Fertilizers on Growth and Yield of Chilli (Capsicum annuum L.), International Journal of Current Microbiology and Applied Sciences, 6(7): 1564-1568.

Nchang, S, Kanaujia, SP, Lal, S, Meena, VK and Tanwar, BS. 2018. Studies on Integrated Nutrient Management on Yield and Quality of Chilli (Capsicum annuum L.), International Journal of Current Microbiology and Applied Sciences, 7(9): 2053-2059

Roberts T.L. 2008. Improving Nutrient Use Efficiency, Turkish Journal Agriculture and Forestry, 32: 177-182.

Saheen A.M., Samad E.H.A. and Rizk F.A.
2016. Growth, yield and fruit quality of sweet pepper (Capsicum annuum L.) in relation to organic and bio-fertilizers application, Agric. Sci. Digest, 4(6): 231223

Sahoo D., Sahoo N.R. and Paramjita D. 2017.Effect of Bio-fertilizers on Yield and Quality of Sweet Pepper (Capsicum annuum cv. grossum L.),J. Indian Soc. Coastal Agric. Res. 35(1): 15-20

Sahoo G., Aslam T., Das S.P., Maity T.K. and Gupta N.K. 2017. A Study on Preflowering Foliar Spray of Plant Growth Regulator on Growth and Yield Parameters in Sweet Pepper (Capsicum annuum L.) Under Protected Condition, International Journal of Current Microbiology and Applied Sciences, 6(7): 3997-4000

Shelat H.N., Vyas R.V., Jhala Y.K., Acharya R.R. and Parmar D.J. 2017. Efficacy of Bio NP Liquid Bio-fertilizers in Chilli Nursery, International Journal Current Microbiology and Applied Sciences, 6(9): 1292-1297

Shilpa, Sharma AK, Thakur S and Sharma K. 2017. Integrated Nutrient Management of Peppers (Capsicum annuum L.) in 21st Century - A Review, International Journal of Current Microbiology and Applied Sciences, 6(12): 227-237

Singh Land Mukherjee S. 2000. Effect of Foliar Application of Urea and NAA on Yield and Yield attributes of chilli (Capsicum annuum var: longum), Agric. Sci. Digest, 20(2): 116-117

Tilak K.V.B.R. and Singh G. 1996. Integrated Nutrient Management in sustainable agriculture. Fertilizer News 41: 29-35

\section{How to cite this article:}

Nikita Mohanty, Ajoy Kumar Pattnaik, Premananda Mahapatra, Nitish Kumar Jena, Siddharth Kumar Rout and Mary Shiny Ekka. 2021. Effect of Macronutrients, Bio-fertilizers and Growth Regulator on Yield and Yield Attributing Characters of Capsicum (Capsicum annuum L.). Int.J.Curr.Microbiol.App.Sci. 10(02): 2899-2906.

doi: https://doi.org/10.20546/ijcmas.2021.1002.322 